\title{
ПРОБЛЕМЫ РОССИЙСКОЙ ЭКОНОМИКИ В СОВРЕМЕННЫХ УСЛОВИЯХ
}

\author{
Галич $E$. A. \\ студентка \\ Кубанского государственного аграрного университета им. И.Т. Трубилина
}

Мамий С.A.

Кандидат экономических наук,дочент

Аннотация. В статье рассматриваются современные проблемы экономических процессов в Российской Федерации. События 2020 года, связанные с распространением коронавирусной инфекции, привели к снижению спроса на энергоресурсы, что существенно отразилось на экономике и социальной сфере России. В статье приводится исследование кризисных явлений, способствующих ухудшению экономической ситуации в стране.

Annotation. The article deals with the current problems of economic processes in the Russian Federation. The events of 2020 associated with the spread of coronavirus infection led to a decrease in demand for energy resources, which significantly affected the economy and social sphere of Russia. The article presents a study of the crisis phenomena that contribute to the deterioration of the economic situation in the country.

Ключевые слова: инвестиции, инфляция, экономика, пандемия, экспорт.

Keywords: investment, inflation, economy, pandemic, exports.

На сегодняшний день экономика страны находится в достаточно тяжелом состоянии. Пандемия коронавируса и связанные с ней ограничения привели к масштабной рецессии, что существенно повлияло на дальнейшее развитие экономики в целом. Нарушение нормального функционирования экономики, сокращение производства и состояние неопределенности может привести к сокращению инвестиций, снижению темпов экономического роста и сокращению капитала.

Масштаб сжатия экономики в России стал одним из наибольших за последние 20 лет. В 2020 году уровень ВВП снизился на 3,1\% (рисунок 1). Основной вклад в падение ВВП в абсолютном выражении внесли: добыча полезных ископаемых, транспорт, торговля и услуги, а в относительном - общественное питание (-24\%), культура и спорт $(-11,4)$.

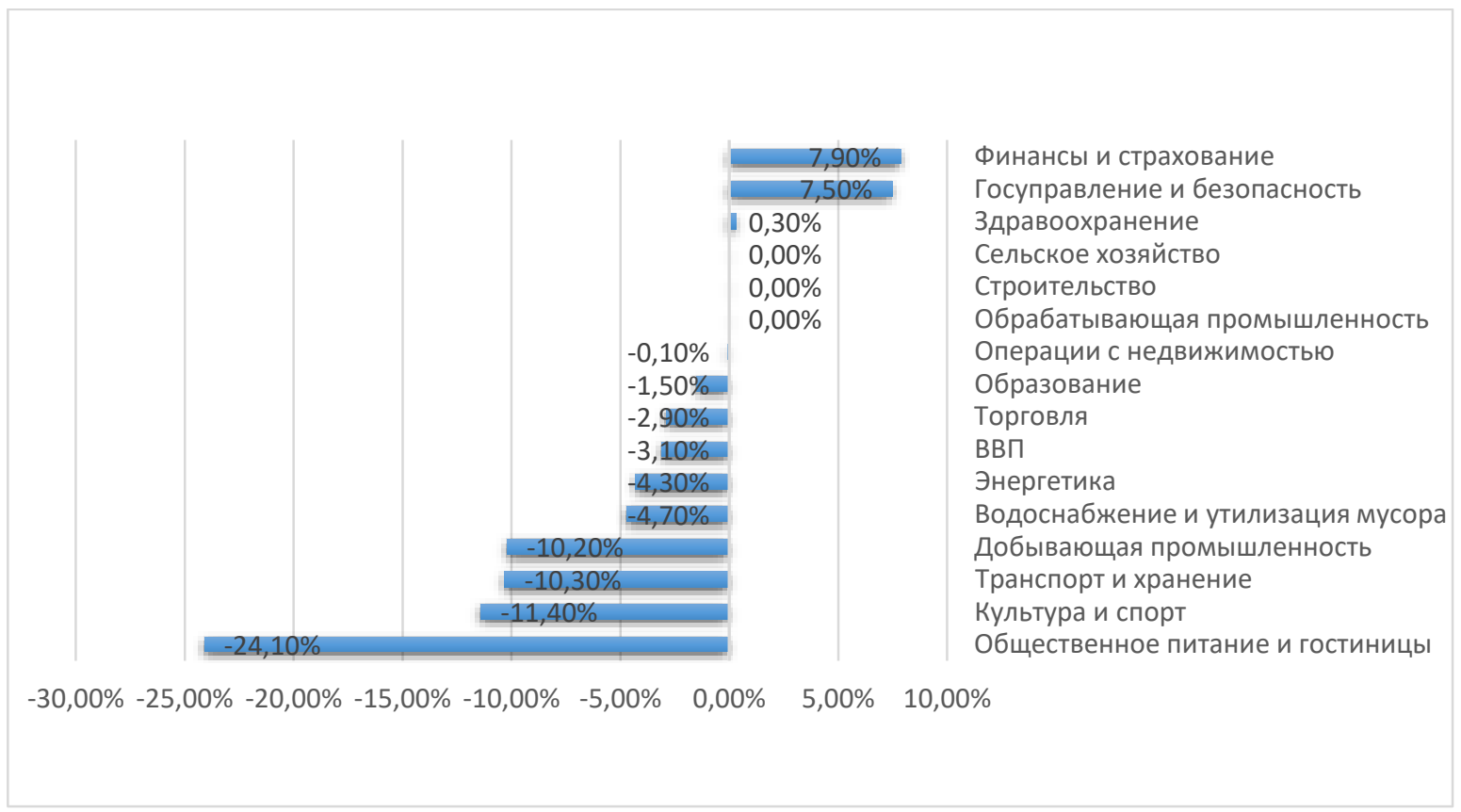

Рисунок 1 - Динамика ВВП и добавленной стоимости по отраслям экономики в 2020 году [1]

Из-за закрытия границ пострадал экспорт и в значительных размерах снизился спрос. Продажи за границу нефти снизились приблизительно на 2,5\%, дерева почти на 10\%, некоторые металлов на $12 \%$ и более.

Пострадали в значительной степени и граждане государства, поскольку рост безработицы во втором квартале 2020 года вырос до 7\%, что привело к снижению реальных доходов населения [5]. Многие частные 
предприниматели прекратили свою деятельность. Малые предприятия сильно пострадали от экономических последствий в период пандемии. Беспрецедентные меры по ограничению распространения коронавирусной инфекции привели к сбоям в цепочке поставок и значительному снижению спроса в большинстве секторов экономики.

Российская Федерация является крупнейшим экспортёром нефти, газа и нефтепродуктов, и цены на нефть по-прежнему выступают ключевым фактором экономического развития отечественной экономики [4]. Снижение цен на нефть ведет к сокращению реального валового внутреннего дохода, который является показателем выпуска отечественной экономики в мировых ценах и покупательной способности произведенного дохода.

В связи с понижением потребностей в нефтепродуктах средняя цена на нефть марки Urals в январедекабре 2020 года сложилась в размере \$41,73 за баррель, в январе-декабре 2019 года — \$63,59 за баррель [2]. Наряду с падением цен на нефть на российскую экономику повлияло снижение спроса на экспортируемые товары. В период пандемии сократился спрос на газ в связи со снижением промышленного производства, также сократился спрос на другие сырьевые товары, зависящие от инвестиционной активности в мировой экономике [3].

Таким образом, развитие российской экономики имеет весьма значительный потенциал, выражающийся в наличии огромных активов внутри страны: запасы природных ресурсов, сырья, рабочей силы. Также необходимо выделить, что слабыми сторонами непосредственно внутри страны остаются факторы, которые характеризуют общественные институты, слабая защита прав собственности, недостаточная развитость инфраструктуры, валютное и налоговое регулирование, преступность. Устранив перечисленные проблемы, экономика России достигнет нового, более высокого уровня социально-экономического развития.

\section{Список литературы:}

1. Дробот Е.В., Макаров И.Н., Назаренко В.С., Манасян С.М. Влияние пандемии COVID-19 на реальный сектор экономики // Экономика, предпринимательство и право. - $2020 . \quad$ - Том $10 . \quad$ - № $8 . \quad-$ C. 2135-2150.

2. Кулькова И.А. Адаптация поведения предпринимателей к вызванным пандемией коронавируса изменениям // Экономика, предпринимательство и право. - 2020. - Том 10. - № 10. - С. 2529-2540.

3. Курс экономической теории. Общие основы экономической теории, микроэкономика, макроэкономика, переходная экономика / ред. А.В. Сидорович. - М.: ДИС, 2021. - 736 с.

4. Макконнелл Экономикс. Принципы, проблемы и политика / Макконнелл, Кемпбелл Р; Брю, Л. Стэнли. - М.: Республика, 2018. - 800 с.

5. Маршалл, А. Принципы экономической науки / А. Маршалл. - М.: Прогресс, 2019. - 735 с. 